\title{
Note on Curricular Proposals of the Medical School in Brazil and Its Articulations with the "Unified Health System (SUS)"
}

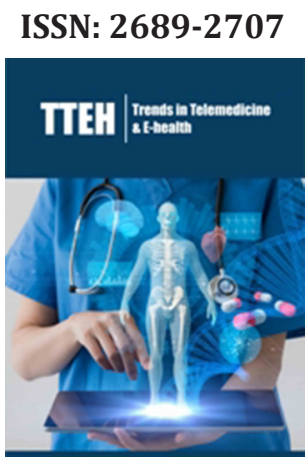

*Corresponding author: Marcos Bagrichevsky PhD, Department of Medicine, Regional University of Blumenau, Santa Catarina, Brazil, E-mail: marcos_bagrichevsky@yahoo.com.br

Submission: 監January 17, 2020

Published: 想January 23, 2020

Volume 2 - Issue 2

How to cite this article: Bagrichevsky M. Note on Curricular Proposals of the Medical School in Brazil and Its Articulations with the "Unified Health System (SUS)". Trends Telemed E-Health 2(2). TTEH. 000534. 2020. DOI: 10.31031/TTEH.2020.02.000534

Copyright@ Marcos Bagrichevsky, This article is distributed under the terms of the Creative Commons Attribution 4.0 International License, which permits unrestricted use and redistribution provided that the original author and source are credited.

\section{Marcos Bagrichevsky*}

Department of Medicine, Regional University of Blumenau, Santa Catarina, Brazil

\author{
Abstract \\ Keywords: Medical education; Curricular project; Unified Health System; Teaching-service integration; \\ Primary care
}

Opinion

Since the implementation of the "Unified Health System (SUS)" in Brazil in 1990 (public system that offers universal access to any citizen, whether employed or not), there have been significant and diversified advances in the formulation of structural policies and programmatic actions of the health sector, directed to the three levels of complexity of the system, with a view to its operationalization/expansion in the country [1].

It is part of this historical advance, unprecedented intersectoral public initiatives that have produced large-scale proposals such as the joint venture of the Ministries of Health and Education, with the aim of redirecting the formation of health professionals in Brazil, including physicians [2-6]. There are numerous successful Brazilian experiences in public health policies that, over the past two decades, have been able to promote impactful changes in educational institutions (universities, mainly), reorganizing in greater or lower magnitude, the curriculum of medical degrees throughout the national territory $[2,7]$.

Among these transformations, I highlight:

A. The inclusion of SUS practice scenarios such as fields of experience/internship mandatory to medical courses/students already in the basic cycle, articulating all at once, the 'qualification of teaching', the 'improvement of health services' and 'community care'-both to constitute new staff of workers of the SUS itself, and to amplify the qualification of physicians already involved in the sector, especially at the level of primary care; and

B. The daily incorporation of another paradigm of health care, guided by the assumptions of Integrality, Equity and critical references of Health Promotion (inspired by the context of Alma-Ata), having as main area of practice the primary health care [8].

However, despite these encouraging progresses, it is worth recognizing that the valorization of the context of humanization of health practices in Brazilian medical education still remains one of the great contemporary challenges to be faced in the country. Even in undergraduate medical curricular projects that have established an important structural reordering $[9,10]$ certain 'internal' ethical-political conflicts still remain ultra-specialized technology is still majority in some undergraduate courses [11,12]. An intriguing situation to say the least. Not only because it is fully feasible to have both articulated approaches in the training of the physician (the mastery of the technique and the critical generalist profile), but, above all, due to such 'compatibility' being concretely formed already, by means of numerous successful experiences throughout Brazil [13-15].

Despite the ideological disputes on the border between 'traditional knowledge' and 'new proposals' for teaching in medical schools, the efforts made over time through interministerial 
actions and programs in Brazil have resulted in irrevocable gains from the point of view of the approximation of the profession with SUS's demands. The "National Curriculum Guidelines of Medical Courses" more recently published [10] confirm the consolidation of such objectives. In the document, the task of incorporating the praxis of integral health care is textually mentioned, which also requires the development of medical skills for interpretive and contextualized reading of health problems in Primary Care [16].

This implies preparing these students to be able to plan and intervene with educational workshops in the health-disease-care process of local populations (also considering their subjective and existential issues), and to build 'Expanded Therapeutic Projects' in the very daily scenarios that integrate 'teaching, service and community'. The advances in curriculum proposals are consolidated and there is much to be a celebrated. However, they are confronted with the sad reality of Brazilian society and the huge challenges we face in public health. Let's see what practical results the future holds.

\section{References}

1. Machado CV, Baptista TVF, Lima LD (2012) Health policies in Brazil. Rio de Janeiro, Fiocruz, Brazil.

2. Dias HS, Lima LD, Teixeira M (2013) The trajectory of the national policy for reorienting professional training in health in SUS. Cienc Saúde Coletiva 18(6): 1613-1624

3. (2002) PROMED: Program to change medicine curriculum launched. Ministry of Health, Saud Report Brasilia, Brazil 158.

4. (2002) General coordination of human resources policy. Incentive program for curricular changes for medical schools (PROMED). Ministry of Health, Health Policy Secretariat, Brasília, Brazil.

5. (2005) Interministerial Ordinance no. 2,101, of November 3, 2005 Institutes the national program for the Reorientation of Professional Training in Health (PRO-HEALTH)-for undergraduate courses in Medicine, Nursing and Dentistry, Ministry of Health, Brazil.
6. (2007) National reorientation program for professional training in health (PRÓ-SAÚDE): Objectives, implementation and potential development. Ministry of Education, Ministry of Health, Brasília, Brazil, p. 86.

7. França T, Magnago C, Santos MR, Belisário SA, Silva CBG (2018) PETHealth/GraduaSUS: Retrospective, differentials and panorama of project distribution. Saúde Debate 42(suppl 2): 286-301.

8. Kalichman AO, Ayres JR (2016) Comprehensiveness and healthcare technologies: A narrative on conceptual contributions to the construction of the comprehensiveness principle in the Brazilian Unified National Health System (SUS). Cad Saúde Pública 32(8): e00183415.

9. (2001) Institutes national curriculum guidelines for the undergraduate medical course. National Education Council. Higher Education Chamber. CNE / CES Resolution no. 4. Official Gazette, Brasília, Brazil, 215: 38.

10. (2014) Institutes national curriculum guidelines for the undergraduate medical course and provides other measures. Ministry of Education. National Education Council. Higher Education Chamber. CNE / CES Resolution no. 3. Official Gazette, Brasília, Brazil, 117: 8-11.

11. Souza PA, Zeferino AMB, Da Ros MA (2011) Integrated medical curriculum: From discourse to practice. Rev Bras Educ Med 35(1): 2025.

12. Silva RA, Fernandez JCA, Barros NF, Nascimento JL (2018) Social science in health, medical education and the interventionist and colonial conception of medical practice. Trab Educ Saúde 16(1): 39-56.

13. Oliveira A, Melo LPP, Pinto TR, Azevedo GD, Santos M, et al. (2017) Integrated experience in the community: Longitudinal health care insertion as medical education strategy. Interface (Botucatu) 21(suppl 1): $1355-1366$.

14. Silva ATC, Medeiros JME, Fontão PN, Saletti FHC, Vital JPF, et al. (2017) Family medicine from the first to the final year of undergraduate medical training: considerations about an educational proposal to integrate service-learning into the curriculum. Rev Bras Educ Med 41(2): 336345 .

15. Maranhão T, Matos IB (2018) Experiences in the Brazilian National Health System (SUS) as events markers in the field of Collective Health. Interface (Botucatu) 22(64): 55-66.

16. Tesser CD (2019) Clinical care and overmedicalization in primary health care. Trab Educ Saúde 17(2): e0020537. 